\title{
Morphometric Study of the Proximal Femur Extremity in Brazilians
}

\author{
Estudio Morfométrico del Extremo Proximal del Fémur en Brasileños
}

\author{
"Eduardo Branco de Sousa; ${ }^{* * * * * *}$ Rodrigo Mota Pacheco Fernandes; ${ }^{* * *}$ Marcelo Bezerra Mathias; \\ ${ }^{* *}$ Mauro Roberto Rodrigues; ${ }^{* * *}$ Albert James Ambram \& **Marcio Antonio Babinski
}

\begin{abstract}
DE SOUSA, E.; FERNANDES, R. M. P.; MATHIAS, M. B.; RODRIGUES, M. R.; AMBRAM, A. J. \& BABINSKI, M. A. Morphometric study of the proximal femur extremity in Brazilians. Int. J. Morphol., 28(3):835-840, 2010.

SUMMARY: Brazilian populational aging besides higher life expectancy has increased the incidence of proximal femoral fractures. Treatment of those fractures uses implants which are based in measurements performed in caucasians, including the 135 degrees cervical-diaphyseal angle. Knowing femoral morphometry allows evaluating implants adequability. We performed our study using 110 Brazilian human femurs (49 right and 61 left). We excluded from the study: bones submitted to osteosyntesis, to prosthetization or those showing abnormalities or malformations which could affect its structure and shape. Bones were submitted to roetgenographic analysis and the images were scanned and transferred to personal computer. Measurements were obtained by AutoCad software and statistics by Graph Pad Instat software. Our data were compared using Kolmogorov-Smirnov and "t-test". The following parameters were evaluated: femoral head diameter (FHD), femoral neck length (FNL), femoral neck width (FNW), femoral axis length (FAL), off-set (OS) and cervicaldiaphyseal angle (CDA). The findings were as follows (mean \pm SD), right and left sides respectively: FHD, $31.1 \pm 2.7 \mathrm{~mm}$ and $30.8 \pm 3.0$ $\mathrm{mm}$; FNL, $30.1 \pm 4.3 \mathrm{~mm}$ and $30.5 \pm 4.1 \mathrm{~mm}$; FNW, $30.96 \pm 2.94 \mathrm{~mm}$; FAL, $98.2 \pm 5.9 \mathrm{~mm}$ and $97.4 \pm 7.13 \mathrm{~mm}$; OS, $42.6 \pm 6.1 \mathrm{~mm}$ and $42.0 \pm 5.6 \mathrm{~mm} ; \mathrm{CDA}, 132.0^{\circ} \pm 7.2^{\circ} \mathrm{e} 131.8^{\circ} \pm 5.2^{\circ}$. Median cervical-diaphyseal angle, obtained in this study presented some variation, which was not statistically significant. Linear data are constant, according to other studies, except the off-set, which has varied.
\end{abstract}

KEY WORDS: Femur; Morphometry; Anatomy.

\section{INTRODUCTION}

The aging of the Brazilian population due to increased life expectancy has led to increased incidence of injuries common in elderly population, such as fractures of the proximal femur (Calis et al., 2004; Ramalho et al., 2001; Silva et al., 2003).

The orthopedic implants used in the treatment of these fractures (fixed-angle plates and hip prostheses) are based on the Caucasian model with cervical-diaphyseal angle of $135^{\circ}$ (Hoaglund \& Low, 1980; DHS/DCS-System standard, 1997). Several studies have evaluated the morphology of the proximal femur in adult cadavers and revealed differences in morphology of the proximal femur in population studies and races (Calis et al.; Silva et al.; Hoaglund \& Low; Isaac et al., 1998; Tahir et al., 2001; Mourão \& Vasconcellos, 2001; Igbigbi \& Msamati, 2002; Canto et al., 2003; Igbigbi, 2003;
Duthie et al., 1998; Michelotti \& Clark, 1999; Karlsson et al., 1996).

The objective of this study is to evaluate morphometric parameters through the proximal femur in Brazilians, promoting discussion of the data obtained with standard domestic and imported implants available.

\section{MATERIAL AND METHOD}

This study, developed at the Department of Morphology in Fluminense Federal University, represent the morphometric study of 110 dry femurs from human, adult and Brazilian cadavers of both sex. Forty-one represent the

* National Institute of Trauma and Orthopaedics (InTO), Brassil.

** Professor of Departament de Morphology. Fluminense Federal University (MMO / UFF), Brassil.

*** Central Hospital of Militar Police (HCPM - PMERJ), Brassil. 
right side. We excluded the bones with visible previous procedures or with signals of undergont bone fixation, or those with visible tumors or deformities that might compromise its structure and form.

The femurs were radiographed using a portable diagnostic model FNX 200, with Kodak-branded film, measuring $30 \times 40 \mathrm{~cm}$. The images were obtained with a distance of the bulb chassis of $100 \mathrm{~cm}$, using a power of $75 \mathrm{kV}$ and $10 \mathrm{~mA}$. We used the anterior-posterior incidence with the femur in internal rotation, placing the lesser trochanter in contact with the chassis. The radiographs were scanned and transferred to the PC.

Measurements were obtained in millimeters, based in the following variables (Fig. 1): 1) femoral head diameter (DCF), 2) length of the femoral neck (the distance between the head and the intertrochanteric line) (CCF) (To define the femoral neck, mark the head with a solid circle and the proximal colon at the intersection of the circle with the lines bordering the neck), 3) width of the femoral neck in its middle third (LCF), 4) distance between the proximal femoral head and lateral cortex of the femur, following the femoral neck axis (CEF), 5) "off-set": distance between the center of the femoral head and femoral diaphyseal shaft (OS) 6) cervical-diaphyseal angle, angle between the axis of the neck and the femur (ACD). The morphometric parameters were measured using the AutoCAD 2000 software. Each measurement was repeated by three observers, using the media as the final result.

The values obtained were statistically analyzed with the software Graph Pad In Stat "through non-parametric tests, to obtain measures of central tendency and dispersion. Measurements were compared with respect to the variables right and left using the "t Student", adopting the level of significance $(\mathrm{p}<0.05)$.

\section{RESULTS}

The values obtained by morphometry are arranged in Table I. When the morphometric parameters were compared between the right and left sides, the differences were not significant (Table I).

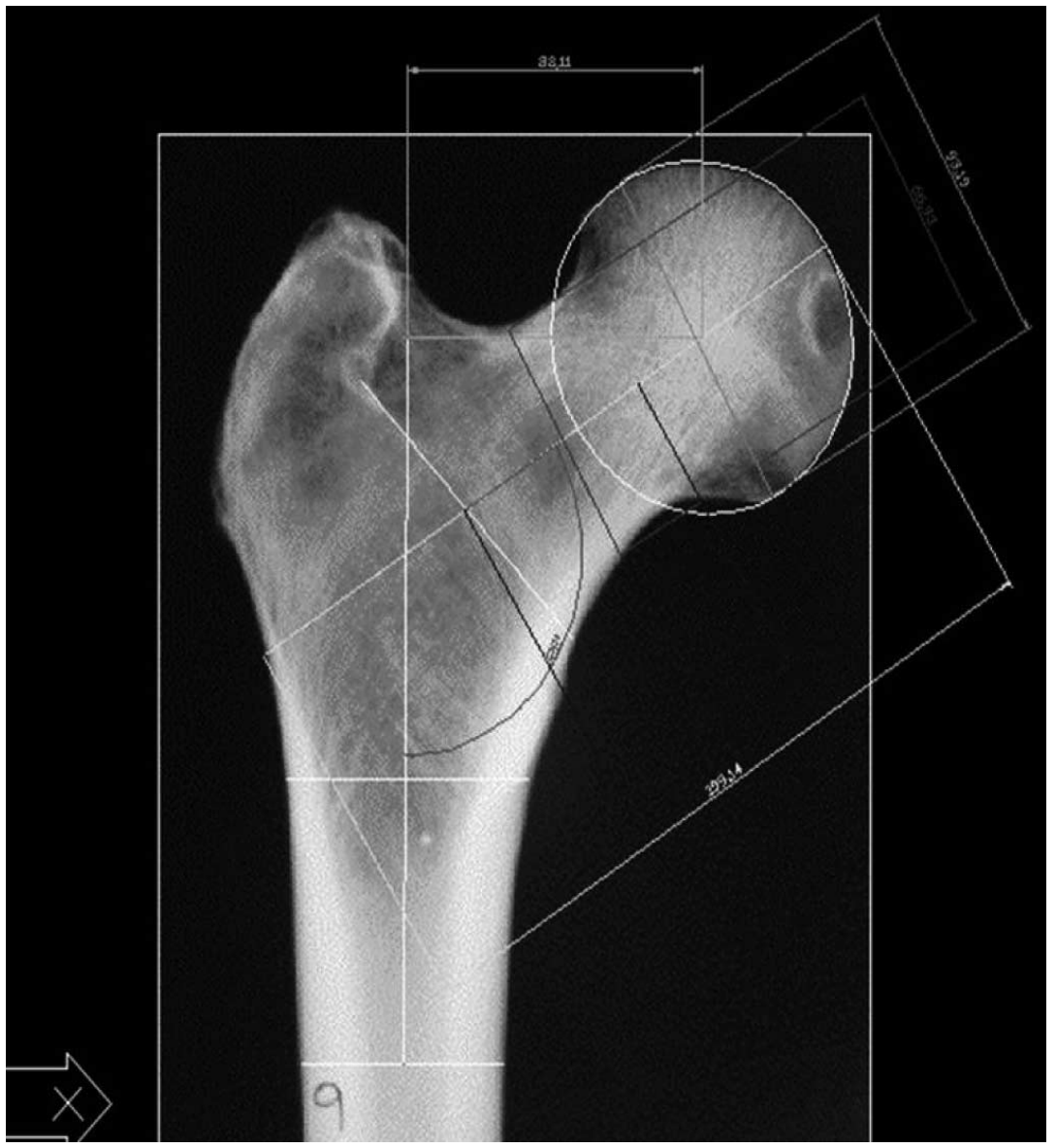

Fig. 1. Morphometry of the proximal femur with AutoCAD 2000 software. Length of the femoral shaft (CEF) in yellow, femoral neck length $(\mathrm{CCF})$ in dark blue; diameter of the femoral head (DCF) in green; width of the femoral (LCF) in red, off-set (OS) in light blue ; cervical-diaphyseal angle in pink. (Source: MMO / UFF). 
DE SOUSA, E.; FERNANDES, R. M. P.; MATHIAS, M. B.; RODRIGUES, M. R.; AMBRAM, A. J. \& BABINSKI, M. A. Morphometric study of the proximal femur extremity in Brazilians. Int. J. Morphol., 28(3):835-840, 2010

Table I. Values of the morphometric analysis of the proximal ends of femora: Mean, standard deviation, minimum, maximum and median.

\begin{tabular}{lcccccccccccc}
\hline & \multicolumn{2}{c}{$\mathrm{ACD}(\mathrm{o})$} & \multicolumn{2}{c}{$\mathrm{CEF}(\mathrm{mm})$} & \multicolumn{2}{c}{$\mathrm{CCF}(\mathrm{mm})$} & \multicolumn{2}{c}{$\mathrm{LCF}(\mathrm{mm})$} & \multicolumn{2}{c}{$\mathrm{DCF}(\mathrm{mm})$} & $\mathrm{OS}(\mathrm{mm})$ \\
\cline { 2 - 12 } & $\mathrm{D}$ & $\mathrm{E}$ & $\mathrm{D}$ & $\mathrm{E}$ & $\mathrm{D}$ & $\mathrm{E}$ & $\mathrm{D}$ & $\mathrm{E}$ & $\mathrm{D}$ & $\mathrm{E}$ & $\mathrm{D}$ & $\mathrm{E}$ \\
\hline $\mathrm{n}$ & 41 & 68 & 41 & 68 & 41 & 68 & 41 & 68 & 41 & 68 & 41 & 68 \\
Mean* & 132.1 & 131.8 & 98.2 & 97.4 & 30.1 & 30.5 & 31.1 & 30.8 & 47.1 & 46.4 & 42.6 & 42.0 \\
$\mathrm{SD}$ & 7.2 & 5.2 & 5.9 & 7.1 & 4.3 & 4.1 & 2.7 & 3.0 & 3.1 & 3.7 & 6.1 & 5.6 \\
Min. & 118 & 120 & 84.6 & 80.5 & 21.9 & 18.4 & 26.1 & 25.0 & 40.8 & 39.5 & 28.5 & 29.5 \\
Mean & 133 & 132 & 99.1 & 97.7 & 30.1 & 31.3 & 30.9 & 31.0 & 47.5 & 47.5 & 42.3 & 42.2 \\
Max. & 152 & 145 & 108.5 & 115.0 & 40.6 & 41.6 & 37.4 & 37.9 & 53.9 & 53.3 & 54.6 & 65.0 \\
p* & \multicolumn{2}{c}{0.8776} & \multicolumn{2}{c}{0.5829} & 0.5693 & 0.6378 & & 0.3011 & 0.5899 \\
\hline
\end{tabular}

Font: Departament of Morphology - UFF / 2009. * Statistical analysis of means between the right and left sides. ACD = cervico-diaphyseal angle; CEF $=$ Length of the femoral shaft CCF $=$ Length of the femoral neck; LCF $=$ Width of the femoral neck; DCF = diameter of the femoral neck, OS = Off-set (Font: MMO / UFF).

\section{DISCUSSION}

Angle Measures (ACD). The ACD is greater at birth, on average 160, and decreases along the skeletal growth, reaching an average of 135 of the adults. This value (135) is used as reference for the manufacture of orthopedic implants used in synthesis or substitution in the proximal femur.

Several studies have evaluated the morphometric patterns of the femur in vivo and dead (Calis et al.; Silva et al.; Isaac et al.; Tahir et al.; Mourão \& Vasconcellos; Igbigbi \& Msamati; Canto et al.; Igbigbi; Duthie et al.; Karlsson et $a l$.). The cervical-diaphyseal angle was study in different races and populations like Norwegian (Isaac et al.), Mexican (Tahir et al.), South Indian (Mourão \& Vasconcellos), Nigerians (Igbigbi \& Msamati), Malaysians (Igbigbi), Ugandans and Kenyans (Duthie et al.), Turks (Michelotti \& Clark), Scottish (Karlsson et al.) and Brazilian (Canto et $a l$.), showing peculiar characteristics in each population studied. Racial variations in cervico-diaphyseal angle was found in many population studies shown on Table II. In agreement with the literature (Table II), this study found wide

Table II. Cervico-diaphyseal angle in different populations and sex.

\begin{tabular}{llll}
\hline Autors & Population & Subdivision & ACD $\left({ }^{\circ}\right)$ \\
\hline These Study & Brazil & Right & $132,1 \pm 7,2$ \\
Mourão \& Vasconcellos & Brazil & Left & $131,8 \pm 5,2$ \\
& & Right & $111,2 \pm 5,9$ \\
Da Silva et al. & Brazil & Left & $114,2 \pm 5,5$ \\
& & Right & $122,55 \pm 4,9$ \\
Hoaglund \& Low & England & Left & $125,61 \pm 6,6$ \\
& China & & 136 \\
Rerikeras et al. & Norwegian & & 135 \\
Garcia et al. & México & & $127,7 \pm 7,6$ \\
Is aac et al. & India (south) & & 130 \\
Tahir et al. & Nigeria & Males & 126,7 \\
Igbigbi \& Msamati & & Females & $136,7 \pm 3,905$ \\
& Malasya & Right & $126,65 \pm 3,397$ \\
Igbigbi & & Left & $121,09 \pm 7,17$ \\
& Uganda & Right & $114 \pm 5,5$ \\
& & Females & $133,4 \pm 5,3$ \\
& Kenia & Right & $123,4 \pm 5,8$ \\
\hline
\end{tabular}

Font: Departament of Morphology - UFF / 2009. 
variation in the measurements of cervico-diaphyseal angle. The average ACD found in this study confronted with data from other studies in Brazillian population, perhaps the methodology in the acquisition of morphometric data have some relation with these findings (Silva et al.; Canto et al.). The authors note that there may be differences between measurements obtained directly from the dry bones, radiological studies of patients and radiographic examination in dry femurs. There are some differences among observers. In this study, we used x-ray image of dry bone specimens, with shortest possible distance between the object and the film, while minimizing the image magnification. We used the software (Autocad 2000) for angular and linear data acquisition, and each measurement was repeated by three observers, using the media as the final result. Therefore, we observed that the variations found among the various population studies are also present in national studies with respect to the ACD, comparing this study with other national (Silva et al.; Canto et al.). Similarly, differences within the same sample, with high standard deviations are observed in almost all studies (Table II) (Silva et al.; Hoaglund \& Low; Isaac et al.; Tahir et al.; Mourão \& Vasconcellos; Igbigbi \& Msamati; Canto et al.; Igbigbi, Duthie et al.).

There are no reports in the literature regarding the incidence of failure of synthesis or under prothesis fractures in specific populations. However, there are references to a higher incidence of fractures of the proximal femur with increased ACD, since rejected by Michelotti \& Clarck and Karlsson et al., which indicates a higher risk of fractures in varus necks, biomechanically more justifiable (Calis et al.; Michelotti \& Clark). The ACD was measured along with other variables in two groups: group 1 , women without hip fractures, and group 2, women with hip fractures. The cervical-diaphyseal angle less (more varus) was considered a risk factor for hip fractures $(\mathrm{p}<0.01)$ (Michelotti \& Clark).
In other studies there was no difference between the sides, as well as this, showing a natural tendency to bilaterality (Silva et al.; Canto et al.; Igbigbi).

Linears Measures. The linear measure search (CEF, CCF, DCF and LCF) found values close to those found in the literature (Hoaglund \& Low; Reikeras et al., 1982; Canto et al.; Igbigbi; Karlsson et al.). Our data were further substantiated and compared with the literature in Table III.

Duthie et al. presented an osteometric study using bones from cadavers. This study has shown significant increase in measures of length and width of the femoral neck for both men and women, suggesting an evolutionary change in the pattern of morphometric population (Scottish) compared to 1920 skeletons with specimens from the 90's. Calis et al. reported an association of femoral geometry, with hip fractures in postmenopausal women, especially in relation to the width of the neck, suggesting in his conclusion best study of geometry to clarify these findings.

The length of the femoral shaft, evaluated in this study showed a mean of $87.74 \pm 6.68 \mathrm{~mm}$, Mourão \& Vasconcellos $92.0 \pm 7.1$, both in Brazil, demonstrating the similarity in the samples. Some authors correlate the EFC as an important element to establish the risk of fractures of the proximal femur, associating this data with bone densitometry (NV1, NV2).

Racial differences in the "off-set", as measured in this work, have not been evaluated by any of the authors mentioned. We believe in the importance of this measure in the production of hip joints to maintain the lever arm of the hip abductor. We find prosthetic femoral components with "off-sets" between 37.4 and 44mm (Garcia \& Uribe, 1995). In this study we found "off-set average of $42.28 \pm 5.79$.

Table III. Comparison of linear measurements in different populations, side and sex.

\begin{tabular}{|c|c|c|c|c|}
\hline Autors & Population & $\mathrm{DCF}(\mathrm{mm})$ & $\mathrm{LCF}(\mathrm{mm})$ & $\mathrm{CCF}(\mathrm{mm})$ \\
\hline These Study & Brazil & $46,56 \pm 3,6$ & $30,96 \pm 2,94$ & $30,4 \pm 4,18$ \\
\hline Da Silva et al. & Brazil & - & - & $\begin{array}{l}D-22,3 \pm 3,3 \\
\text { E - } 23,5 \pm 3,6\end{array}$ \\
\hline Mourão \& Vasconcellos & Brazil & - & $\begin{array}{l}D-26,7 \pm 3,1 \\
E-26,3 \pm 3,3\end{array}$ & $\begin{array}{l}D-24,9 \pm 4,5 \\
E-24,3 \pm 4,2\end{array}$ \\
\hline Hoaglund \& Low & $\begin{array}{c}\text { England } \\
\text { China }\end{array}$ & $\begin{array}{l}46 \\
45\end{array}$ & $\begin{array}{l}33 \\
31\end{array}$ & \\
\hline Dutchie et al. & S cothland & $\begin{array}{l}M-50,2 \pm 0,6 \\
F-45,2 \pm 0,6\end{array}$ & $\begin{array}{c}M-35,8 \pm 0,6 \\
F-32,1 \pm 0,4\end{array}$ & $\begin{array}{c}M-32,5 \pm 0,9 \\
F-35 \pm 0,7\end{array}$ \\
\hline Igbigbi \& Msamati & Malasya & - & $\begin{array}{l}\text { D - } 26,7 \pm 3,1 \\
\text { E - } 26,3 \pm 3,3\end{array}$ & $\begin{array}{l}\text { D - } 24,9 \pm 4,5 \\
\text { E - } 24,3 \pm 4,2\end{array}$ \\
\hline
\end{tabular}

Font: Departament of Morphology $-\mathrm{UFF} / 2009$. Legend: D= Right / E= Left / M= Male / F= Female / DCF= Diameter of femoral head / LCF= width of the femoral neck) / $\mathrm{CCF}=$ length of the femoral neck. 
We have different models of hip arthroplasty design, with "off-sets" between $33 \mathrm{~mm}$ and $52 \mathrm{~mm}$ and length neck / head from 39 to $556 \mathrm{~mm}$, making it possible, in most cases anatomic reconstruction allowing the biomechanics of locomotion (Garcia \& Uribe; Reikeras et al.).

Neither study showed significant differences of sex or side measures in linears measures (Silva et al.; Hoaglund \& Low; Canto et al.; Igbigbi; Karlsson et al.).

In conclusion, the cervico-diaphyseal angle average variations are not significant. The linear measurements have remained constant in line with other studies, except the parameter "offset" that showed variability.

DE SOUSA, E.; FERNANDES, R. M. P.; MATHIAS, M. B.; RODRIGUES, M. R.; AMBRAM, A. J. \& BABINSKI, M. A. Estudio morfométrico del extremo proximal del fémur en Brasileños. Int. J. Morphol., 28(3):835-840, 2010.

RESUMEN: Junto al envejecimiento de la población de Brasil, producto de la mayor expectativa de vida, ha aumentado la incidencia en las fractura de la parte proximal del fémur. Para el tratamiento de estas fracturas se utilizan implantes, los que estan basados en mediciones realizadas en caucásicos, incluido los 135 grados del ángulo cervico-diafisario. Conocer la morfometría femoral permite evaluar adecuabilidad de los implantes. Se realizó este estudio con 110 fémures humanos (49 derechos y 61 izquierdos) de individuos brasileños. Se excluyeron del estudio: los huesos sometidos a osteosíntesis, a prótesis o en los que se detectaron anormalidades o malformaciones que pudieran afectar su estructura y forma. Los huesos fueron sometidos a análisis radiográfico y las imágenes digitalizadas y transferidas a un computador personal. Las mediciones se obtuvieron mediante el software AutoCAD y las estadísticas con el software Instat. Nuestros datos se compararon con la prueba de Kolmogorov-Smirnov y "t-test". Los siguientes parámetros fueron evaluados: diámetro de la cabeza del fémur (FHD), longitud del cuello femoral (FNL), ancho del cuello femoral (FNW), longitud del eje del fémur (FAL), off-set (OS) y el ángulo cérvico-diafisario (CDA). Los resultados fueron los siguientes (media \pm SD), a la derecha e izquierda respectivamente: FHD, 31,1 $\pm 2,7 \mathrm{~mm}$ y $30,8 \pm 3,0 \mathrm{~mm}$; FNL $30,1 \pm 4,3 \mathrm{~mm}$ y $30,5 \pm 4,1 \mathrm{~mm}$; FNW $30,96 \pm 2,94 \mathrm{~mm}$; FAL $98,2 \pm 5,9 \mathrm{~mm}$ y $97,4 \pm 7,13 \mathrm{~mm}$; OS 42,6 $\pm 6,1 \mathrm{~mm}$ y 42,0 $\pm 5,6 \mathrm{~mm}$; CDA $132,0^{\circ} \pm 7,2^{\circ}$ y $131,8^{\circ} \pm 5,2^{\circ}$. Los ángulos cérvico-diafisarios medianos obtenidos en este estudio presentaron alguna variación, que no fue estadísticamente significativa. Los datos lineales fueron constantes en acuerdo con otros estudios, excepto el off-set, que ha variado.

\section{PALABRAS CLAVE: Fémur; Morfometría; Anatomía.}

\section{REFERENCES}

Calis, H. T.; Eryavuz, M. \& Calis, M. Comparison of femoral geometry among cases with and without hip fractures. Yonsei Med. J., 45(5):901-7, 2004.

Canto, R. S. T.; Silveira, M. A.; Rosa, A. S.; Gomide, L. C. \& Baraúna, M. A. Morfologia radiográfica de quadril e pelve e sua relação com fraturas proximais do fêmur. Rev. Bras. Ortop., 38(1/2):12-20, 2003.

DHS/DCS-System standard. Surgical technique. SYNTHES, instruments and original implants from AO / ASIF, 1997. Porous Hip Prostheses. VerSys Hip System, Zimmer, 1997.

Duthie, R. A.; Bruce, M. F. \& Hutchison, J. D. Changing proximal femoral geometry in north east Scotland: an osteometric study. Brit. Med. J., 316:1498, 1998.

Garcia, F. G. \& Uribe, A. R. Antropomorfometria endóstica del fémur proximal en población mexicana. Rev. Mex. Ortop. Traumatol., 9(2):59-70, 1995.

Hoaglund, F. T. \& Low, W. D. Anatomy of the femoral neck and head, with comparative data from caucasians and Hong
Kong chinese. Clin. Orthop. Rel. Res., 152:10-6, 1980.

Igbigbi, P. S. Collodiaphyseal angle of the femur in East African subjects. Clin. Anat., 16(5):416-9, 2003.

Igbigbi, P. S. \& Msamati, B. C. The femoral collodiaphyseal angle in Malawian adults. Am. J. Orthop., 31(12):6825, 2002.

Isaac, B.; Vettivel, S.; Prasad, R. \& Chandi, G. Prediction of the femoral neck-shaft angle from the length of the femoral neck. Clin. Anat., 10(5):318-23, 1998.

Karlsson, K. M.; Sernbo, I.; Obrant, K. J.; Redlund-Johnell, I. \& Johnell, O. Femoral neck geometry and radiographic signs of osteoporosis as predictors of hip fracture. Bone, 18:327-30, 1996.

Michelotti, J. \& Clark, J. Femoral neck length and hip fracture risk. J. Bone Miner. Res., 14:1714-20, 1999.

Mourão, A. L. \& Vasconcellos, H. Geometria do fêmur proximal em ossos de brasileiros. Acta Fisiatr., 8(3):113-9, 2001. 
DE SOUSA, E.; FERNANDES, R. M. P.; MATHIAS, M. B.; RODRIGUES, M. R.; AMBRAM, A. J. \& BABINSKI, M. A. Morphometric study of the proximal femur extremity in Brazilians. Int. J. Morphol., 28(3):835-840, 2010.

Ramalho, A. C.; Castro, M. L.; Hauache, O.; Vieira, J. G.; Takata, E.; Cafalli, F. \& Tavares, F. Fractures of proximal femur: clinical and epidemiological fractures in a population of the city of São Paulo. São Paulo Medical J., 119(2):48-53, 2001.

Reikeras, O.; Hoiseth, A.; Reigstad, A. \& Fonstelien, E. Femoral neck angles: a specimen study with special regard to bilateral differences. Acta Orthop. Scand., 53(5):775-9, 1982.

Silva, V. J.; Oda, J. Y. \& Sant'anna, D. M. G. Anatomical aspects of the proximal femur of adult brazilians. Int. J. Morphol., 21(4):303-8, 2003.

Tahir, A.; Hassan, A. W. \& Umar, I. M. A study of the collodiaphyseal angle of the femur in the North-Eastern Sub-Region of Nigeria. Niger. J. Med., 10(1):34-6, 2001.
Correspondence to:

Prof. Dr. Rodrigo M.P. Fernandes

Departamento de Morfologia (Anatomia)

Instituto de Biomédico

Universidade Federal Fluminense (UFF)

Rua Ernani Mello, 101, São Domingos

CEP 24.210-150

Niterói, RJ

BRAZIL

Fax: (55) (21) 2629-2336.

Email: rodrigomota@vm.uff.br rodrigouff@gmail.com

Received: 30-03-2010

Accepted: 28-05-2010 